\title{
PENINGKATAN KEMAMPUAN BERPIKIR KRITIS DAN PRESTASI BELAJAR KIMIA MATERI POKOK KELARUTAN DAN HASIL KALI KELARUTAN DENGAN MODEL DISCOVERY LEARNING BERBANTUAN MIND MAP DI KELAS XI IPA 2 SEMESTER GENAP SMA MUHAMMADIYAH 1 KARANGANYAR TAHUN PELAJARAN 2016/2017
}

\section{Zunia Rizky Wanda Lailasari, Budi Utami ${ }^{*}$, dan Nurma Yunita Indriyanti}

Program Studi Pendidikan Kimia, FKIP,Universitas Sebelas Maret, Surakarta, Indonesia

*Keperluan Korespondensi, HP: 081227973456, email: budiutami@staff.uns.ac.id

\begin{abstract}
ABSTRAK
Penelitian ini bertujuan untuk meningkatkan kemampuan berpikir kritis dan prestasi belajar siswa dengan model pembelajaran discovery learning berbantuan mind map pada materi kelarutan dan hasil kali kelarutan garam kelas XI IPA 2 SMA Muhammadiyah 1 Karanganyar tahun pelajaran 2016/2017, Penelitian ini merupakan Penelitian Tindakan Kelas (PTK) yang dilakukan dalam dua siklus, tiap siklusnya terdapat empat tahapan, yaitu perencanaan, pelaksanaan, observasi, dan refleksi. Subjek penelitian adalah siswa kelas XI IPA 2 SMA Muhammadiyah 1 Karanganyar tahun pelajaran 2016/2017. Teknik pengumpulan data melalui observasi, wawancara, kajian dokumen, angket dan tes, dengan deskriptif kualitatif. Hasil penelitian menunjukkan bahwa penerapan model pembelajaran discovery learning berbantuan mind map dapat meningkatkan kemampuan berpikir kritis dan prestasi belajar siswa pada materi kelarutan dan hasil kali kelarutan garam kelas XI IPA 2 SMA Muhammadiyah 1 Karanganyar. Pada siklus I, ketercapaian siswa dengan kemampuan berpikir kritis tinggi sebesar $77 \%$ dan pada siklus II meningkat menjadi 100\%, pada aspek afektif ketercapaian siklus I sebesar $94 \%$ dan meningkat menjadi $100 \%$ pada siklus II. Pada aspek kognitif ketercapaian ketuntasan siklus I sebesar $34 \%$ dan meningkat menjadi $68 \%$ pada siklus II. Pada aspek psikomotor ketercapaian pada siklus I sebesar $100 \%$.
\end{abstract}

Kata kunci: penelitian tindakan kelas, discovery learning, mind map, kemampuan berpikir kritis, prestasi belajar

\section{PENDAHULUAN}

Menurut Undang-Undang Sisdiknas nomor 20 tahun 2003, pendidikan adalah usaha sadar dan terencana untuk mewujudkan suasana belajar dan proses pembelajaran agar peserta didik secara aktif mengembangkan potensi dirinya untuk memiliki kekuatan spiritual keagamaan, pengendalian diri, kepribadian, kecerdasan, akhlak mulia, serta keterampilan yang diperlukan dirinya, masyarakat bangsa dan negara[1].

Di Indonesia, mutu pendidikan sudah mulai diperbaiki dengan melakukan pembaharuan kurikulum yang terdahulu dan perbaikan sarana pra- sarana. Kurikulum Tingkat Satuan Pendidikan memiliki salah satu tujuan untuk meningkatkan kualitas pendidikan di Indonesia. Dalam pembelajaran KTSP (Kurikulum Tingkat Satuan Pendidikan) sistem penilaian meliputi tiga aspek yaitu : aspek kognitif, aspek afektif dan aspek psikomotor [2]. Pada kurikulum tingkat satuan pendidikan ini pembelajaran sudah tidak berpusat pada guru namun menjadi berpusat pada peserta didik, sehingga menuntut siswa untuk aktif dalam proses pembelajaran yang terjadi didalam kelas.

Di SMA Muhammadiyah 1 Karanganyar, guru masih cenderung mengunakan metode ceramah dan 
penggunaan media pembelajaran yang masih kurang, sehingga membuat potensi peserta didik dan kemampuan berpikir kritis mereka masih belum berkembang. Kemampuan berpikir kritis adalah pemikiran yang beralasan dan dan reflektif yang berfokus pada memutuskan apa yang harus dipercayai atau dilakukan [3]. Menurut Brookfield dengan berpikir kritis siswa dapat belajar berpikir, menulis, dan berbicara secara kritis[4]. Oleh karena itu semakin tinggi kemampuan berpikir kritis siswa maka semakin tinggi juga kualitas pembelajaran yang dihasilkan.

Kelas XI IPA 2 merupakan kelas yang memiliki kemampuan berpikir kritis yang rendah hal ini terbukti dari hasil ter berpikir kritis yang menunjukkan bahwa sebanyak 44,68\% siswa memiliki kemampuan berpikir kritis rendah, $23,40 \%$ siswa memiliki kemampuan berpikir kritis sedang dan $31,93 \%$ siswa memiliki kemampuan berpikir kritis yang tinggi.

Berdasarkan hasil wawancara dengan guru mata pelajaran kimia di SMA Muhammadiyah 1 Karanganyar, pada pembelajaran kimia siswa yang memenuhi batas ketuntasan masih kurang dari $50 \%$, khususnya untuk kelas XI IPA 2 yang memiliki ketuntasan belajar yang rendah sekitar $10-20 \%$ dan salah satu materi yang kurang dikuasai oleh siswa kelas XI IPA SMA Muhamadiyah 1 Karanganyar adalah materi kelarutan dan hasil kali kelarutan. Pada materi ini siswa masih mengalami kesulitan dalam pemahaman konsep dan perhitungan yang ada pada materi kelarutan dan hasil kali kelarutan. Hal ini dikarenakan pada materi ini siswa lebih sering menghafal materi dari pada memahaminya sehingga pemahaman yang diperoleh siswa terbatas.

Berdasarkan hasil observasi yang dilakukan di kelas XI IPA 2 SMA Muhammadiyah 1 Karanganyar, diketahui bahwa siswa belum aktif dalam proses pembelajaran, prestasi belajar siswa yang masih tergolong rendah, kurang pahamnya siswa pada materi Kelarutan Dan Hasil Kali Kelarutan, serta masih tergolong rendahnya kemampuan berpikir kritis siswa.
Salah satu solusi yang dapat digunakan yaitu dengan pembelajaran discovery (belajar penemuan). Pembelajaran discovery learning menunjukkan bahwa peserta didik tidak diberikan informasi target atau pemahaman konseptual dan harus menemukan secara mandiri dan hanya dengan materi yang telah disediakan [5]. Pada pembelajaran ini siswa akan saling bertukar pendapat dan saling berdiskusi untuk memecahkan suatu masalah sehingga pada kesimpulan akhirnya mereka akan menemukan suatu konsep dan prinsip secara sendirinya. Pembelajaran dengan discovery learning akan mendorong pemahaman siswa terhadap suatu konsep akan menjadi semakin dalam dengan kemampuan berpikir kritis siswa yang semakin tinggi [6]. Hal tersebut didukung dengan penelitian yang dilakukan Nugrahaeni yang menyatakan bahwa dengan penerapan model pembelajaran discovery learning dalam kelas dapat meningkatkan kemampuan berpikir kritis siswa dan hasil belajar kimia[7].

Menurut Zhang terdapat tiga hal utama dalam pembelajaran discovery learning yaitu (1) menggambarkan masalahan dan membuat pernyataan umum,(2) menguji pernyataan yang telah dirumuskan dengan eksperiment atau informasi yang valid dan (3) refleksi [8].Selain itu, model pembelajaran discovery learning dapat mendorong minat belajar siswa sehingga membuat siswa menjadi aktif dan lebih mudah lama memahami materi [9].

Penggunaan media pembelajaran dapat membantu dalam proses belajar. Media pembelajaran yang digunakan pada penelitian ini adalah mind map. Media mind map dianggap cocok karena mind map ini merupakan media mencatat yang menyenangkan dan efektif dalam memperoleh dan mengumpulkan informasi yang akan masuk dan keluar pada otak seseorang, dengan menggunakan suatu gambar atau symbol yang akan membuat informasi lebih mudah diingat [10]. Maka dari itu dengan penggunaan media mind map siswa dapat melatih logika dan kretivitas mereka secara bersamaan [11]. 
Berdasarkan uraian latar belakang di atas, maka perlu dilakukan penelitian tindakan kelas (PTK) mengenai penggunaan model discovery learning berbantuan mind map pada materi kelarutan dan hasil kali kelarutan garam di XI IPA 2 untuk meningkatkan kemampuan berpikir kritis siswa dan prestasi belajar.

\section{METODE PENELITIAN}

Penelitian yang dilakukan merupakan penelitian tindakan kelas (PTK). Dalam melaksanakan penelitian tindakan kelas dibutuhkan empat tahap yaitu 1) perencanaan (planning), 2) tindakan (acting), 3) pengamatan (observing), 4) refleksi (reflecting). Subjek penelitian adalah siswa kelas XI IPA 2 SMA Muhammadiyah 1 Karanganyar tahun pelajaran 2016/2017. Pemilihan subjek dalam penelitian berdasarkan pada observasi awal dan wawancara guru, dimana subjek teridentifikasi memiliki permasalahan dalam pembelajaran yaitu berpikir kritis dan pretasi belajar yang rendah.

Data yang dikumpulkan meliputi data keadaan siswa yang berupa data kualitatif dan kuantitatif. Data aspek kualitatif berupa observasi, wawancara, dan angket yang menggambarkan proses pembelajaran di kelas sedangkan data aspek kuantitatif yang dimaksud adalah hasil penilaian kemampuan berpikir kritis siswa dan prestasi belajar siswa yang meliputi kognitif,sikap, dan psikomotor pada siklua I dan siklus II.

Teknik analisis data pada penelitian ini menggunakan analisis deskriptif, Analisis data menggunakan beberapa tahap yaitu 1) tahap reduksi data, 2) tahap penyajian data, 3) tahap penarikan kesimpulan dan teknik triangulasi atau pengujian kabsahan dan uji kevalidan [12]

\section{HASIL DAN PEMBAHASAN}

Pada awal penelitian dilakukan observasi, wawancara, kajian dokumen dan angket untuk mengetahui kondisi awal siswa. Dari hasil wawancara menunjukkan bahwa siswa masing mengalami kesulitan dalam memahami materi kimia khususnya materi kelarutan dan hasil kali kelarutan dan kemampuan siswa dalam berpikir kritis masih rendah sehingga perlu ditingkatkan, selain itu berdasarkan pada hasil observasi awal menunjukkan siswa cendurung pasif dalam proses pembelajaran.

Hasil kajian dokumen menunjukkan bahwa ketuntasan nilai siswa untuk materi kimia masih rendah, khususnya pada kelas XI IPA 2. Sedangkan hasil prasiklus kemampuan berpikir kritis siswa menunjukkan bahwa masih banyak siswa yang memiliki kemampuan berpikir kritis yang rendah. Sehingga perlu dilakukan suatu tindakan untuk mengatasi masalah yaitu dengan menerapkan model discovery learning berbantuan mind map. Menurut Baharuddin dan Wahyuni (2007) salah satu model pembelajaran yang dapat mempengaruhi domain kognitif dan keaktifan siswa adalah discovery learning [13]. Selain itu berdasarkan penelitian dari Nugrahaeni (2017) disimpulkan bahwa dengan menggunakan model discovery learning dapat meningkatkan kemampuan berpikir kritis siswa [7].

\section{Siklus I}

\section{a. Perencanaan Tindakan}

ini, peneliti menyususn silabus berdasarkan data silabus dari guru, dan membuat perencanaan pelaksanaan pembelajaran (RPP) berdasarkan silabus tersebut yang kemudian dikaji bersama dengan guru. Setelah itu peneliti menyusun instrument berpikir kritis,aspek kognitif, aspek afektif dan penilaian aspek psikomotor.

Berdasarkan data silabus, alokasi waktu untuk materi kelarutan dan hasil kali kelarutan garam sebanyak 10 jam pelajaran, yang kemudian dibagi menjadi 4 kali pertemuan dimana setiap pertemuan menerapkan model discovery learning berbantuan mind map. Penggunaan mind map menurut Edward dan Cooper (2010) merupakan cara efektif dalam memperoleh informasi, selain itu dengan visualisasi gambar membuat informasi lebih mudah untuk diingat[14]. Maka dari itu, pada penelitian ini media mind map digunakan sebagai 
bahan bantu dalam proses pembelajaran.

\section{b. Pelaksanaan Tindakan}

Pada tahap pelaksanaan tindakan siklus I dilakukan sebanyak 4 kali pertemuan, dimana 3 pertemuan digunakan untuk menyampaikan materi sedangkan 1 kali pertemuan dilakukan untuk evaluasi. Pelaksanaan tindakan di awali dengan memberikan apersepsi kepada siswa, memberikan motivasi dan menyampaikan tujuan dan model pembelajaran kepada siswa. Pada kegiatan pendahuluan guru membagi siswa menjadi 7 kelompok. kemudian guru memberikan suatu stimulation kepada siswa, yang bertujuan untuk merangsang rasa ingin tahu dan berpikir siswa dan siswa diminta untuk mengidentifikasi masalah dan membuat suatu.

Setelah itu, siswa menggunakan mind map dan sumber literature lain yang akan digunakan untuk membuktikan pernyataan yang mereka buat, dan mengolah data yang diperoleh untuk mengerjakan lembar diskusi secara kelompok dengan berbantuan mind map yang telah ditugaskan oleh siswa. Setelah diskusi selesai, siswa kembali ke tempat duduk masing- masing dan perwakilan siswa menyampaikan hasil diskusi untuk membuktikan pernyataan yang mereka buat serta siswa menarik kesimpulan dari permasalahan yang di berikan oleh guru. Setelah itu, guru mengevalusi hasil diskusi siswa dan memberikan memberikan penguatan konsep materi. Pada akhir pembelajaran guru dan siswa bersama- sama menyimpulkan hasil pembelajaran yang dimanfaatkan agar lebih paham mengenai materi yang telah diajarkan. Selain itu guru memberikan tugas berupa pembuatan mind map untuk materi selanjutnya.

Pertemuan kedua dan ketiga tidak jauh berbeda dengan pertemuan pertama, tetapi keaktifan siswa pada pembelajaran menjadi lebih meningkat.Pada pertemuan keempat dilakukan evaluasi siklus 1 meliputi aspek kemampuan berpikir kritis, aspek kognitif, dan aspek afektif.

\section{c. Observasi Tindakan}

Hasil observasi selama proses pembelajaran berlangsung menunjukan bahwa terjadi peningkatan keaktifan siswa pada setiap pertemuan meskipun belum seluruhnya siswa aktif dalam pembelajaran. Analisis hasil tes pada siklus I dapat dibuat dalam beberapa kategori-kategori. Hasil penilaian kemampuan berpikir kritis siswa dapat dibuat kategori seperti pada Gambar 1.

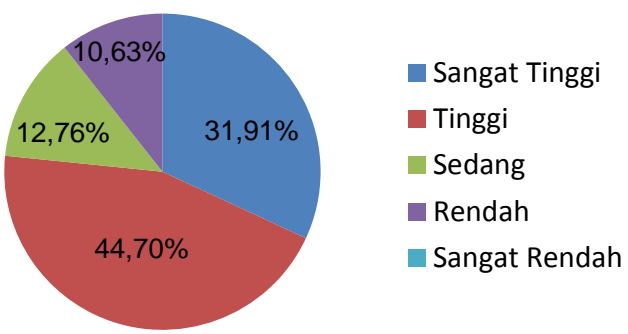

Gambar 1. Persentase Nilai Kemampuan Berpikir Kritis Siklus I

Gambar 1 menunjukkan bahwa secara umum kemampuan berpikir kritis siswa pada siklus I telah memenuhi target ketercapaian yaitu $75 \%$ dengan kategori tinggi dan sangat tinggi, namun terdapat 4 indikator kemampuan berpikir kritis yaitu indikator 1) menentukan masalah dari suatu peristiwa, 3) yaitu memahami arti kata, indikator 4) membuat kesimpulan logis, 7) mengevaluasi berdasarkan fakta, yang capaiannya masih dibawah target sehingga perlu dilanjutkan pada siklus II. Penilaian kemampuan berpikir kritis berupa benar dan salah yang dikategorikan menjadi 5 kategori pengelompokkan yaitu sangat tinggi, tinggi,sedang rendah dan sangat rendah [15].

Hasil penilaian aspek kognitif dapat dilihat pada Gambar 2.

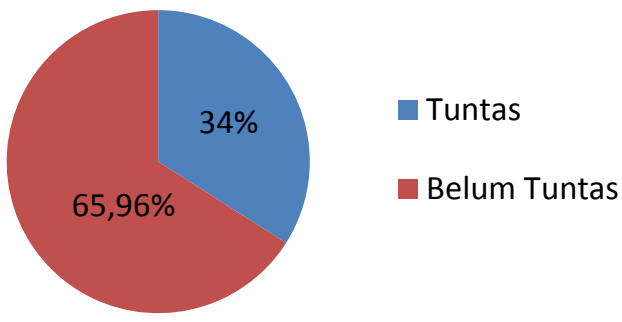

Gambar 2. Persentase Ketuntasan Belajar Aspek Kognitif Siklus I 
Gambar 2 menunjukkan bahwa siswa yang tuntas pada aspek kognitif masih di bawah target yaitu 65\%. Pada hasil siklus I terdapat tiga indikator yang belum tuntas yaitu menjelaskan pengaruh ion senama, menjelaskan pengaruh $\mathrm{pH}$ terhadap kelarutan dan memperkirakan terbentuknya endapan berdasarkan kelarutan, sehingga perlu dilanjutkan pada siklus II.

Hasil penilaian aspek afektif dapat dilihat pada Gambar 3.

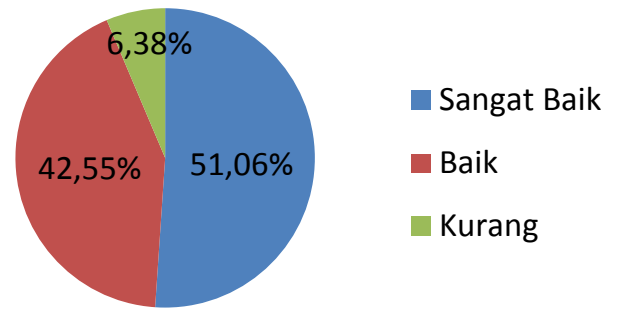

Gambar 3. Persentase Ketuntasan Aspek Afektif Siklus I

Dari analisis aspek afektif yang telah dilakukan pada 47 siswa yang berada dalam kelas XI IPA 2 SMA Muhammadiyah Karanganyar menunjukkan bahwa sebanyak 51,06\% siswa masuk dalam katerogi sangat baik, siswa yang masuk dalam kategori baik sebanyak $42,55 \%$ siswa, sedangkan untuk kategori kurang baik sebanyak siswa $6,38 \%$ siswa. Berdasarkan hasil tersebut aspek afektif telah memenuhi target ketercapaian yaitu $75 \%$.

Hasil penilaian aspek psikomotor di sajikan pada Gambar 4.

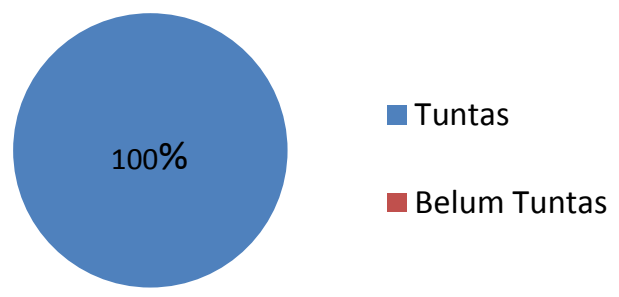

Gambar 4. Persentase Ketuntasan Penilaian Aspek Psikomotor

Berdasarkan Gambar 4 menunjukkan bahwa semua siswa sudah mencapai ketuntasan pada penilaian psikomotor yang berupa pembuatan mind map.

\section{d. Refleksi Tindakan}

Berdasarkan hasil analisis pada siklus I menunjukkan bahwa masih terdapat aspek yang belum mencapai target yaitu kemampuan berpikir kritis dan aspek kognitif. Hal ini diakibatkan karena terdapat beberapa siswa yang tidak memperhatikan guru dan pasif dalam pembelajaran sehingga membuat siswa masih kesulitan dalam memahami materi,kurang telitinya siswa dalam pengerjaan tes serta kurangnya waktu dalam proses pengerjaan tes yang dilakukan pada siklus I. Oleh karena itu, perlu dilaksanakan siklus II yang diharapkan dapat mencapai target yang sudah ditentukan.

\section{Siklus II}

\section{a. Perencanaan}

Tindakan siklus II lebih difokuskan untuk perbaikan terhadap kendalakendala yang ada pada siklus I dan hanya difokuskan pada materi dengan indikator-indikator yang belum mencapai ketuntasan yaitu menjelaskan pengaruh ion senama, menjelaskan pengaruh $\mathrm{pH}$ terhadap kelarutan dan memperkirakan terbentuknya endapan berdasarkan kelarutan. Pada siklus II guru juga mendorong siswa untuk lebih aktif pada proses belajar mengajar dan memberikan pemahaman lebih mengenai materi.

\section{b. Pelaksanaan}

Pada pembelajaran yang dilakukan di siklus II guru lebih menfokuskan pada materi-materi yang belum dipahami pada siklus I yaitu pengaruh ion senama, pengaruh $\mathrm{pH}$ terhadap kelarutan dan memperkirakan terbentuknya endapan berdasarkan kelarutan. Pada siklus II menunjukkan bahwa siswa menjadi lebih aktif dalam proses pembelajaran dan menyelesaikan soal diskusi yang diberikan oleh guru.

\section{c. Observasi Tindakan}

Hasil observasi menunjukkan bahwa siswa menjadi lebih aktif pada siklus II dari pada siklus I. Analisis tes yang sudah dilakukan pada siklus II dapat dilihat dari hasil masing-masing aspek dapat dilihat pada masing-masing 
aspek yaitu kemampuan berpikir kritis, kognitif dan afektif.

Hasil penilaian kemampuan berpikir kritis pada siklus II dapat dilihat pada Gambar 5.

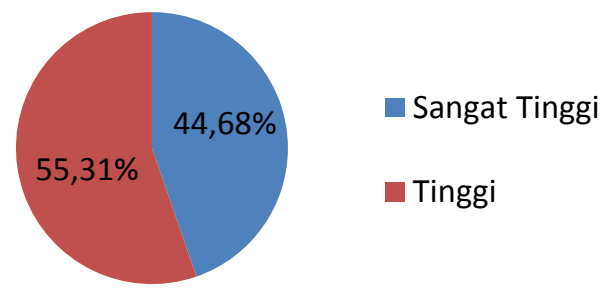

Gambar 5. Persentase Nilai Kemampuan Berpikir Kritis Siklus II

Berdasarkan pada Gambar 5 menujukkan bahwa kemampuan berpikir kritis siswa untuk kategori tinggi dan sangat tinggi telah memenuhi target ketercapaian yaitu $75 \%$. Semua indikator kemampuan berpikir kritis siswa juga sudah mencapai target sehingga penilaian aspek kemampuan berpikir kritis diakhiri pada siklus II.

Hasil penilaian aspek kognitif siklus II disajikan pada Gambar 6

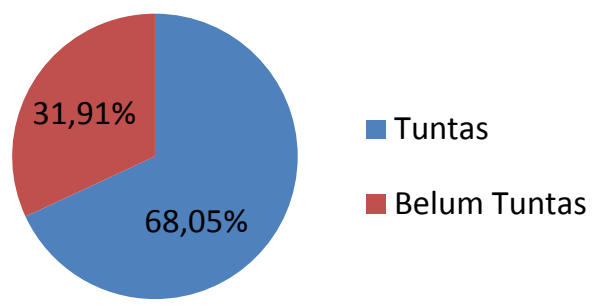

Gambar 6. Ketuntasan Aspek Kognitif Siklus II

Gambar 6 menunjukkan bahwa pada aspek kognitif telah mencapai batas ketercapaian yaitu $65 \%$ sedangkan pada hasil siklus II aspek kognitif siswa mencapai $68,05 \%$ siswa yang tuntas.

Hasil penilaian aspek afektif dapat kita lihat pada Gambar 7.

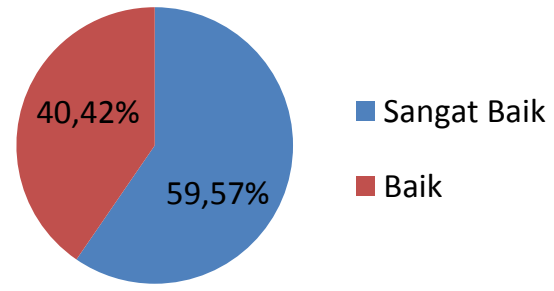

Gambar 7. Ketuntasan Aspek Afektif Siklus II
Berdasarkan Gambar 7 pada siklus II pada aspek afektif mengalami peningkatan dari siklus I dan telah memenuhi taget ketercapaian yaitu sebesar $70 \%$ untuk kategori baik dan sangat baik.

\section{d. Refleksi}

Berdasarkan hasil analisis siklus II menunjukkan bahwa semua aspek telah memenuhi target ketercapaian, sehingga penelitian berakhir pada siklus II.

\section{Perbandingan Hasil Antar Siklus}

Perbandingan hasil antarsiklus dilakukan untuk mengetahui peningkatan hasil tindakan pada siklus I dan siklus II. Berdasarkan hasil penilaian tindakan siklus I dan siklus II diperoleh peningkatan hasil dari semua indikator kerja yang dinilai.

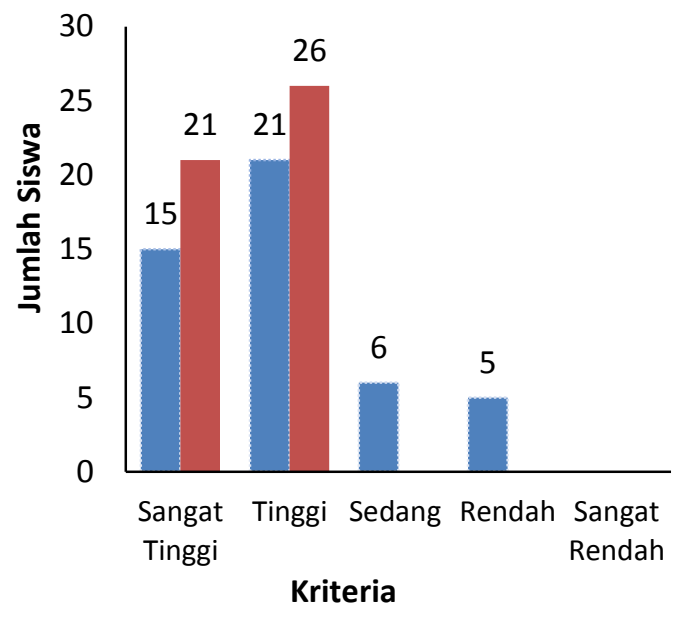

- Siklus 1 Siklus 2

Gambar 8. Analisis Kemampuan Berpikir Kritis Siklus I Dan Siklus II

Berdasarkan Gambar 8 dapat dilihat bahwa terdapat peningkatan pada siklus II dimana pada siklus II sudah tidak terdapat siswa yang tergolong siswa yang memiliki kemampuan berpikir kritis sedang dan rendah. Pada hasil siklus II ini menunjukkan bahwa telah terjadi peningkatan dengan kemampuan berpikir kritis siswa, yang mana pada siklus II ini hanya terdiri dari siswa dengan kemampuan berpikir kritis yang sangat tinggi dan siswa dengan kemampuan berpikir kritis tinggi. Penggunaan disvcovery learning dapat 
melatih kemampuan berpikir kritis siswa lebih baik [16].

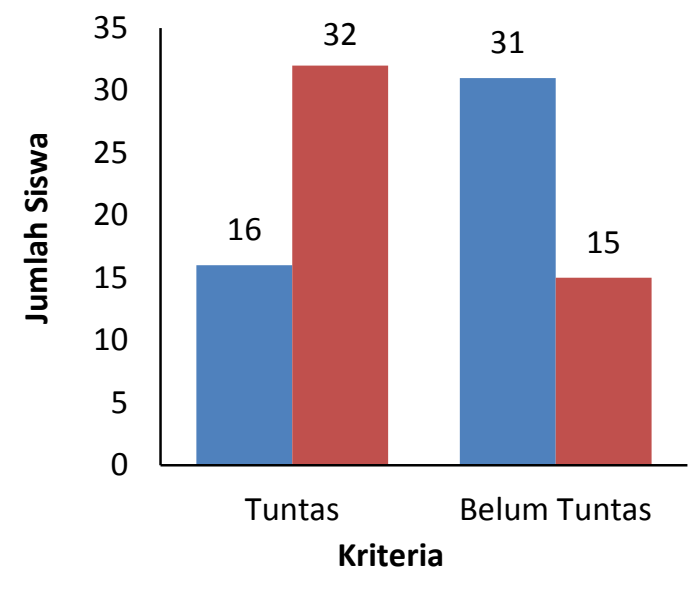

- Siklus 1 Siklus 2

Gambar 9. Ketuntasan Aspek Kognitif Siklus I dan Siklus II

Berdasarkan Gambar 9 dapat dilihat bahwa terjadi peningkatan aspek kognitif dari siklus I ke siklus II. Peningkatan aspek kognitif sebesar $34,05 \%$ atau 15 siswa telah mencapai batas ketuntasan.

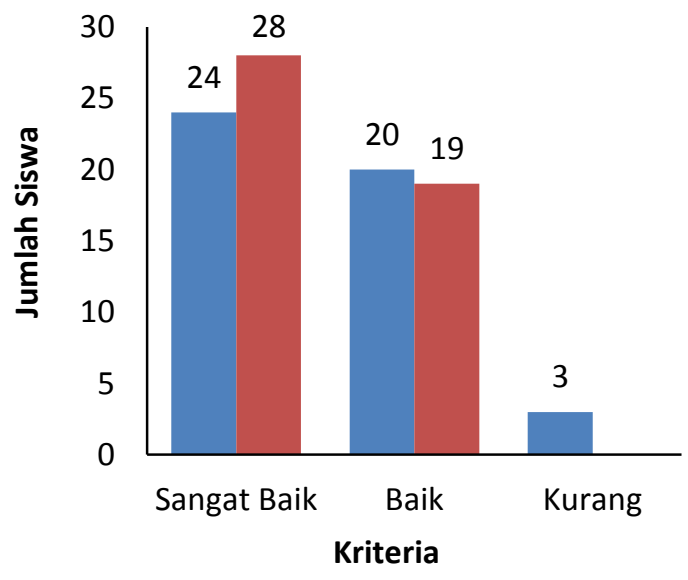

Siklus 1 Siklus 2

Gambar 10. Ketuntasan Aspek Afektif Siklus I dan Siklus II

Berdasarkan Gambar 10 yang telah disajikan diatas dapat dilihat bahwa pada siklus I dan siklus II mengalami perubahan, pada siklus I menunjukkan bahwa masih terdapat siswa yang memiliki aspek afektif yang kurang baik sebesar $6 \%$, sedangkan untuk siklus II sudah tidak terdapat siswa yang memiliki aspek afektif yang kurang baik. Hal ini menunjukkan bahwa terdapat peningkatan pada siklus II.

Berdasarkan uraian hasil dan pembahasan, penelitian dengan menggunakan model pembelajaran discovery learning berbantuan mind map dapat dikatakan berhasil dalam meningkatkan kemampuan berpikir kritis dan prestasi belajar siswa. Indikator kerja yaitu meliputi kemampuan berpikir kritis, aspek kognitif, aspek afektif, dan aspek psikomotor siswa telah mencapai target.

\section{KESIMPULAN}

Berdasarkan hasil penelitian maka dapat disimpulkan bahwa penerapan model pembelajaran discovery learning berbantuan mind map pada materi kelarutan dan hasil kali kelarutan dapat meningkatkan kemampuan berpikir kritis siswa (77\% pada siklus I menjadi $100 \%$ pada siklus II) dan prestasi belajar siswa (aspek kognitif 34\% pada siklus I menjadi $68,05 \%$ pada siklus II, aspek afektif 93,61\% pada siklus I menjadi 100\% pada siklus II, dan aspek psikomotor $100 \%$ pada siklus I) di kelas XI IPA 2 SMA Muhammadiyah 1 Karanganyar tahun pelajaran 2016/2017.

\section{UCAPAN TERIMA KASIH}

Penulis mengucapkan terima kasih kepada Bapak Munfarid, S.Ag., M.Pdl selaku kepala SMA Muhammadiyah 1 Karanganyar dan kepada lbu Rizala Noer Aini, S.Pd selaku guru kimia yang telah memberikan ijin kepada penulis untuk menggunakan kelas XI IPA 2 untuk penelitian, serta kepada siswa-siswi kelas XI IPA 2 SMA Muhammadiyah 1 Karanganyar tahun pelajaran 2016/2017 yang telah membantu penulis dalam menyelesaikan penelitian ini.

\section{DAFTAR RUJUKAN}

[1] Departemen Pendidikan Nasional. (2003). Undang- Undang Nomor 20 Tahun 2003 tentang Sistem Pendidikan Nasional. Jakarta: Depdiknas.

[2] Yamin, M. (2007). Kiat Membelajarkan Siswa. Jakarta: Gaung Persada Press. 
[3] Fisher, A. (2006). Critical Thingking An Introduction. Inggris: Cambridge University Press.

[4] Brookfield, S. D. (1997). "Assesing Critical Thinking”. New Direction for Adult and Continuing Education: Jossey- Bass Publisher.

[5] Tenenbaum, Harriet R. (2011). Does Discovery- Based Intruction Enhance Learning?. Artikel. City University of New York.

[6] Eggen, Paul dan Don Kauchack. (2012). Strategi dan Model Pembelajaran Mengajarkan Konten dan Keterampilan Berpikir. Jakarta: PT Indeks

[7] Nugrahaeni, A, Redhana,W., Kartawan A,M,I. (2017). Jurnal Pendidikan Kimia Indonesia. Vol 1 (1). 23-29.

[8] Reid, D.J., J. Zhang \& Q. Chen. (2003). Journal of Computer Assistend Learning. 19. 9-20.

[9] Puspitadewi,R., Saputro, A.N.C., Ashadi. (2016). Jurnal Pendidikan Kimiai. Vol 5(4). 114-119.
[10] D'Antoni, A, et al. (2010). "Does the Mind Map Learning Strategy Facilitate Information Retrievel \& Critical Thinking in Medical Students?". BMC Medical Educationi.

[11] Buzan, Tony. (2007). Buku Pintar Mind Map. Jakarta: PT. Gramedia Pusaka Utama.

[12] Sugiyono. (2013). Metode Penelitian Pendidikan. Bandung: Alfabeta

[13] Baharuddin, $\mathrm{H}$ dan Wahyuni, N. (2010). Teori Belajar dan Pembelajaran. Yogyakarta : ArRuzz Media.

[14] Edward, S dan Nick Cooper.(2010). The Clinical Teacher. Vol 7. 236-239.

[15] Azwar, S. (2012). Penyusunan Skala Psikologi. Yogyakarta: Pustaka Belajar

[16] Jong, Ton De \& Wouter Van Joolingen. (1998). Journal Review of Education Research. 68. 179202. 